\title{
REFLECTION OF ENGLISH READING CURRICULUM IN JUNIOR HIGH SCHOOL TEXTBOOKS: IMPLICATION FOR CURRICULUM DEVELOPMENT
}

\author{
Bukhori \\ State Islamic University of Sultan Syarif Kasim Riau, Indonesia \\ bukhori.elmeskumy@gmail.com
}

\begin{abstract}
This study investigates the reflection of English reading curriculum in Junior High School textbooks in terms of types of syllabus, reading tasks and cognitive level of reading tasks. Two books have been employed as documents to be analyzed in this research. The first book is Bahasa Inggris Sekolah Pertama Kelas VIII Edisi 4 which is one of electronic textbooks (Buku Sekolah Elektronik (BSE)) published by Department of National Education. The second book is English on Sky (EOS)2 for Junior High School Students Year VIII from Erlangga publisher. The findings suggested that both BSE and EOS have reflected a part of English reading curriculum. In this case BSE is better than EOS. However, both textbooks need to be improved in fulfilling the curriculum demand in terms of types of reading tasks and cognitive levels of reading tasks. Based on the research findings, some recommendations for curriculum development are finally presented.
\end{abstract}

Key words: English reading curriculum, textbook, syllabus, types of reading task, cognitive levels of reading task

\begin{abstract}
ABSTRAK
Studi ini mengkaji refleksi kurikulum mata pelajaran membaca bahasa Inggris di buku teks SMP yang berkaitan dengan jenis silabus, jenis tugas membaca dan tingkat kognitif tugas membaca. Dua buku telah digunakan sebagai dokumen yang akan dianalisis dalam penelitian ini. Buku pertama adalah Bahasa Inggris Sekolah Pertama kelas VIII Edisi 4 yang merupakan salah satu buku elektronik (Buku Sekolah Elektronik (BSE)) yang diterbitkan oleh Departemen Pendidikan Nasional. Buku kedua adalah English on Sky (EOS)2 for Junior High School Students Year VIII dari penerbit Erlangga. Temuan menunjukkan bahwa kedua BSE dan EOS telah mencerminkan bagian dari kurikulum membaca bahasa Inggris. Dalam hal ini BSE lebih baik dari EOS. Namun, kedua buku perlu ditingkatkan dalam memenuhi tuntutan kurikulum dalam hal jenis tugas membaca dan tingkat kognitif tugas membaca. Berdasarkan hasil penelitian, beberapa rekomendasi untuk pengembangan kurikulum akhirnya disajikan.
\end{abstract}


Kata Kunci: English reading curriculum, textbook, syllabus, types of reading task, cognitive levels of reading task

\section{A. Introduction}

Reading is the process by which people gain information and ideas from printed materials, such as books, newspapers, letters, contracts, advertisements and a host of other materials ${ }^{1}$. As a receptive skill, reading is essential in stimulating literacy of language. Some studies have found that reader's language proficiency in a foreign language is directly correlated with their ability to generate inferences in foreign language reading ${ }^{2}$. Without reading comprehension skills that lead to information literacy, students' academic performance could be severely handicapped due to their inability to acquire the required content. Moreover, Patel and Jain (2008) state that reading is an important activity which one can update his / her knowledge and as an important tool for academic success $^{3}$.

Regarding the importance of reading, the latest curriculum known as Kurikulum Tingkat Satuan Pendidikan (KTSP) focuses teaching English in Indonesia based

1 Blachowicz, C. \& Ogle, D. 2008. Reading Comprehension: Strategies for Independent Learners. $\left(2^{\text {nd }} e d\right)$. New York: Guilford Press. p. 15

${ }^{2}$ Barry \& Lazarte, 1998; Hammadou, 1991 cited in Sidek, H. M. 2010. An Analysis of the EFL Secondary Reading Curriculum in Malaysia: Approaches to Reading and Preparation for Higher Education. Unpublished Thesis. University of Pittsburgh.

${ }^{3}$ Patel, M. F \& Jain, P. M. 2008. English Language Teaching (Methods, Tools \& Techniques). Jaipur: Sunrise Publishers \& Distributors. p.113 on four literacy levels including performative, functional, informational and epistemic. These four literacy levels are integrated in four language skills: listening, speaking, reading and writing ${ }^{4}$. For Junior high school, teaching reading covers understanding meanings in simple written interpersonal and transactional discourse, both formally and informally, in the form of recount, narrative, procedure, descriptive, and report, in daily life contexts 5 .

In applying this curriculum, department of education has prepared English textbooks as standard guidelines for the teachers in teaching English. These textbooks can be downloaded by the teachers and students freely. Besides, book publishers have also published English books that can be used by the teachers and students. It is observable that most of English teachers use text books whether it is from government of publishers in teaching and learning process.

Realizing the use of textbook in teaching English widely, especially teaching reading, an evaluation of textbooks is a must, because textbooks should reflect all the components of curriculum demands. Moreover, the quality of a textbook will influence the result of

${ }^{4}$ BNSP. (2006). Kurikulum Tingkat Satuan Pendidikan: Standar Kompetensi dan Kompetensi Dasar. Jakarta: Departemen Pendidikan Nasional

${ }^{5}$ BNSP. (2006). Kurikulum Tingkat Satuan Pendidikan: Standar Kompetensi dan Kompetensi Dasar. Jakarta: Departemen Pendidikan Nasional 
teaching and learning process. Therefore, this paper studies the reflection of English reading curriculum in junior high school textbooks released by government and publisher under the following research questions:

1. What types of syllabus is reflected in Junior high school text books?

2. What types of reading tasks are reflected in junior high school textbooks?

3. What levels of cognitive demand are reflected in reading tasks of junior high school textbooks?

There are some studies have been conducted in terms of textbook evaluation. Çakit (2006) assessed the effectiveness of an intermediate textbook titled "New Bridge to Success 3", which was prepared by Ministry of National Education as an instructional material for the ninth grade high school students from the perspectives of the teachers and students. The results revealed that both teachers and students felt negative about the most of the characteristics of the textbook. It was found that the reading passages needed to be simplified in terms of both vocabulary load and structures. Majority of the students and all the teachers mentioned that the level of the textbook was not appropriate for the particular age group. It also indicated that the materials failed to consider learning style preferences of the visual, auditory, and kinesthetic learner. On the other hand, one of the strengths of the textbook was the artwork's being up-to date and helpful for the students to understand the lesson ${ }^{6}$.

Aytug (2007) explored English teachers' attitudes towards the evaluation of the textbook New Bridge to Success for 9th Grade New Beginners (NBS) and the study also investigated teachers' perceptions concerning main characteristics of a model ELT textbook designed for high school students in Ankara. The study was conducted with 60 English teachers from 13 different Anatolian High Schools in Ankara during June 2006. According to the analyses, teachers' evaluations depicted agreement and disagreement considering the features of the textbook NBS. The findings also showed that the researcher's own observations of the textbook elements correspond to the teachers' evaluations. On the other hand, there are a number of aspects wherein the participants' responses reflect discrepancies when compared with the analysis of the textbook by the researcher. ${ }^{7}$

Alamri (2008) evaluated the quality of the sixth grade English language textbook for Saudi boys' schools which was introduced at the elementary stage by the Ministry of Education in 2004. This research project evaluates a new textbook

\footnotetext{
${ }^{6}$ Çakit, I. 2006. Evaluation of the Efl Textbook "New Bridge To Success 3" from the Perspectives of Students and Teachers. Unpublished Thesis. Graduate School of Social Sciences of The Middle East Technical University

${ }^{7}$ Aytug, S. 2007. An EFL Textbook Evaluation Study in Anatolian High Schools: 'New Bridge to Success for 9th Grade New Beginners'. Unpublished Thesis. Ankara: The Department of Teaching English as a Foreign Language. Bilkent University.
} 
that is considered to be the foundation stone in the English language program in Saudi Arabia. The findings were generally in favour of the textbook except the for the teaching methods and some other sub-items. Out of 64 items in the questionnaire, only 13 items had arithmetic means less than 2.50 . The category that had the highest mean was the one on learning components, while the category that had the lowest mean was the one on teaching methods. The findings also revealed that there were no significant differences between the means of the two populations of the study (teachers and supervisors) except on the flexibility of the textbook and the different natures of their jobs might be the reason behind this difference. The study concluded with recommendations and suggestions for the improvement of the textbook ${ }^{8}$.

Kayapinar

investigated on the teachers' views on the quality of foreign coursebook packages (from beginner to intermediate level) widely used in the teaching process of English preparatory classes in twenty five different high schools. In the study, widely used (best selling) coursebooks with the same subdomains are chosen to be evaluated by teachers. The views reveal that teachers do not have positive impressions about the coursebook packages used in general. Moreover, the general conceptions of the teachers suggest that coursebooks should be developed and used to

\footnotetext{
${ }^{8}$ Alamri, A. A. M. 2008. Textbook for Saudi Boys' Schools. Unpublished Thesis. The College of Arts. King Saud University
}

meet the needs of the learners in the national context. ${ }^{9}$

Sidek (2010) examined the overarching approaches to the second language reading instruction reflected in the Malaysian EFL secondary curriculum and how well this curriculum prepares students for tertiary reading in EFL. The findings indicate that the Malaysian EFL secondary reading curriculum frequently uses reading as an explicit skill to achieve the listed learning outcomes in the EFL Secondary Curriculum. Nonetheless, the curriculum is developed based on the cognitive information processing theory of SLA, TopDown theory of L2 reading reflecting Non-Interactive Whole Language instruction as well as learner roles that are primarily in the form of individual tasks. The findings on passage analysis show that the EFL textbook primarily uses narrative passages with the majority of passages below grade-level length. The curriculum, however, emphasizes reading tasks that require high cognitive demand as well as important types of reading tasks. $^{10}$

Tok (2010) examined the advantages and disadvantages of one type of TEFL materials, English language textbook "Spot On", used in state primary schools in Turkey. Sample of the research consists of 46 English teachers chosen

\footnotetext{
${ }^{9}$ Kayapinar, U. 2009. Coursebook Evaluation by English Teachers. Inonu University Journal of the Faculty of Education. Volume. 10, Issue. 1, pp. 69-78

${ }^{10}$ Sidek, H. M. 2010. An Analysis of the EFL Secondary Reading Curriculum in Malaysia: Approaches to Reading and Preparation for Higher Education. Unpublished Thesis. University of Pittsburgh
} 
randomly from state primary schools in Malatya and Adiyaman city centres. The research revealed that 'Spot On' textbook actually did not stand up reasonably well to a systematic in-depth analysis and that the negative attributes far outweighed the positive characteristics. $^{11}$

\section{Soleimani \& Dabbaghi} (2012) evaluated the efficiency of the New Interchange course books in terms of providing sufficient and comprehensible pragmatic input for Iranian learners of English to fulfill their basic communicative needs based on the content of the books. The study also intended to evaluate the ability of Iranian learners of English in dealing with different speech situations. Descriptive statistical analyses revealed a high index of standard deviation which indicated a large disparity in pragmatic knowledge of students at the above mentioned level of proficiency. Also Since high achiever's managed to respond to all speech situations using the information provided in their books, it was concluded that the books provided enough pragmatic input for language learners to deal with their basic communicative needs. Findings of the study pedagogically call for using EFL materials which provide sufficient pragmatic input for language learners. ${ }^{12}$

\footnotetext{
${ }^{11}$ Tok, H. 2010. TEFL Textbook Evaluation: From Teachers' Perspectives. Educational Research and Review Vol. 5 (9), pp. 508-517

${ }^{12}$ Soleimani, H \& Dabbaghi, A. 2012. Textbook evaluation: A reflection on the New Interchange Series. International Journal of Research Studies in Language Learning. Volume 1 Number 2, 19-32
}

Ling, Tong, \& Jin (2012) examined 53 international ESL intermediate learners' perceptions of reading texts for a period of 14 weeks reading proficiency lessons, in order to provide an evaluation of the suitability of reading texts from the perspective of students in university-based intensive English programme, Features evaluated include content, readability, exploitability, and authenticity of the reading texts. Results indicated the extent of appropriateness of the reading texts incorporated in the programme's reading textbook used by intermediate learners of English. Further consideration must be given to text selection by including the aspect of authentic text presentation. $^{13}$

These previous studies indicate that textbook evaluation have been conducted in terms of the effectiveness of textbooks, teachers' attitudes toward textbooks, quality of textbooks, advantages and disadvantages of textbooks, the efficiency of textbooks, and students' perceptions of text. However, specific discussion on reflection of English reading curriculum in junior high school textbooks in Indonesia is likely uninvestigated yet. Thus, this study tries to cover this issue.

\section{B. Review of the Literature English Reading Curriculum of Junior High School in Indonesia}

Teaching English at junior high school aims to provide students who have competence in

\footnotetext{
${ }^{13}$ Ling, Y. C., Tong, C. S., \& Jin, N. Y. 2012. Evaluating the ESL Reading Texts for Intermediate Learners of English from the Perspective of Students. Global Journal of Human Social Science. Volume 12 Issue 7
} 
developing communicative competence in written and oral forms in achieving functional literacy level, (2) having awareness on the importance of English in improving competitiveness in the global era, and (3) developing students' understanding on the relationship between language and culture. ${ }^{14}$ The aims are described in several standard competences and basic competences. The competence standard of reading for the first semester of grade VIII is understanding meaning of functional written text and simple short essay in descriptive and recount. Basic competence of this competence standard can be simplified into (1) reading aloud of descriptive and recount text by using received pronunciation, stress and intonation (2) responding the meaning of functional written text and simple short essay in descriptive and recount, and (3) responding the meaning and rhetoric of functional written text and simple short essay in descriptive and recount. For the second semester, competence standard of reading is understanding meaning of simple short essay in recount and narrative. This competence consist of (1) reading aloud of recount and narrative text by using received pronunciation, stress and intonation (2) responding the meaning of functional written text and simple short essay in recount and narrative, and (3) responding the meaning and rhetoric of functional written text and simple short essay in recount and narrative.

\footnotetext{
${ }^{14}$ BNSP. (2006). Op.cit.
}

\section{Syllabus design}

In implementing curriculum, the English teacher needs to translate the standard competences stated in curriculum in form of syllabus. Generally, a syllabus is defined as a specification of the content of a course of instruction and lists what will be taught and tested ${ }^{15}$. There is a consensus over the concept of syllabus as summarized by Brumfit: ${ }^{16}$

1. A syllabus is the specification of school or college work organized in subsections defining the work of a particular group or class;

2. Often linked to time and specify ultimate goals;

3. Specify some kind of sequence;

4. Document of administrative convenience and it is negotiable and adjustable;

5. Specify what is taught not what is learned;

6. And it is a public document which expresses accountability.

As part of curriculum, a syllabus is a very important document to teachers because it is the basis for the content delivered to the learner. According to the Southern African Development Community Ministries of Education (2000) there are some reasons why it is important to have a syllabus ${ }^{17}$ :

\footnotetext{
${ }^{15}$ Richard, J.C. 2001. Curriculum Development in Language Teaching. New York: Cambridge University Press. P.2

${ }^{16}$ Al-Murabit, I. A. 2012. A Closer Look at an English Language Curriculum of a Community College in Saudi Arabia. English Language Teaching. Vol. 5 No. 8, 226-242

${ }^{17}$ The Southern African Development Community Ministries of Education. 2000. Module 14: Curriculum Practice. The Commonwealth of Learning.
} 
1. From the syllabus, the teacher can determine what topics are to be taught at each level: class, grade or form.

2. The syllabus outlines terminal objectives. It gives the teacher the basis for evaluation, since these objectives specify the expected achievements at the end of the course.

3. The syllabus lists concepts to be developed; it tells the teacher what pupils should learn. The syllabus outlines the learning experiences and provides notes on the subject to be learned. These help the teacher determine the depth of the content and the expected skills to be developed. The teacher can easily prepare materials needed to deliver lessons.

4. The syllabus provides strategies and means of evaluating the learners' understanding of the subject

Translating general goals at the curriculum level through specific objectives at the syllabus level occurs on three concerns of syllabus: the dimension of language content, process and product or outcomes. Each dimension is developed based on the theory of language, language learning or a particular philosophy of education and becomes basic component of instructional plan. In line with this idea, Nation \& Macalister (2010) proposed these dimension by using another terms called content and sequencing, format and presentation, and monitoring and assessment. ${ }^{18}$

\footnotetext{
${ }^{18}$ Nation, I.S.P and Macalister, J. 2010. Language Curriculum Design. New York and London: Routledge. P.38-39
}

In syllabus design, there are five possible types of syllabus: (1) the linear format (2) the modular format (3) the cyclical format (4) the matrix format and (5) the story-line format. The linear format is appropriate with discrete element content, particularly grammar or structure. However, a strict linear shape does not work well when the categories of language content are notional or functional. The modular format is suitable to courses which integrate thematic or situational language content with a skills orientation regarding the course outcomes as well as the matrix format. But the matrix format gives the users maximum flexibility to select topic from the table contents in random order. The cyclical format allows teacher and learners to work in the same topic more than once which is categorized more complex or difficult level. In this syllabus shape, new subject matter should be reintroduced in different manifestations at various times in the course. The story-line format has the effect of ensuring thematic continuity and of helping to resolve questions of the ordering of categories in relation to one another. ${ }^{19}$

With different perspective, Krahnke (1987) elaborates six types of language teaching syllabus: (1) structural syllabus focusing on grammar, (2) notional/ functional syllabus focusing on language use, (3) situational syllabus focusing on real or situational language use, (4) skill-based syllabus focusing on

\footnotetext{
${ }^{19}$ Dubin, F and Olshtain, E. 1987. Course Design: Developing Programs and Materials for Language Learning. Cambridge, New York and Melbourne: Cambridge University Press. P. 51-61
} 
language skills, (5) task-based syllabus focusing on task and activities of language learning, and (6) content-based syllabus focusing on content being taught. ${ }^{20}$ Moreover, Brown (1995) adds two types of syllabus, namely: (1) topical syllabus concerning with selected topic chosen by the author of textbook, and (2) mixed or layered syllabus blending two types of syllabus ${ }^{21}$.

Regarding to several types of syllabus stated, Nunan (1989) distinguishes these types of syllabus into two categories: productoriented syllabuses and processoriented syllabus. Product-oriented syllabuses (structural/ formal, situational, lexical and notional/functional syllabus) are those in which the focus is on the knowledge and skills which learners should gain as a result of instruction, while process syllabuses (taskbased, procedural, negotiated, proportional and content-based syllabus) are those which focus on the learning experiencing themselves. ${ }^{22}$

On the other hand, Wilkins (1976) draws a distinction between synthetic and analytic types of syllabuses. A synthetic syllabuses organize language in different parts which are taught separately and

${ }^{20}$ Krahnke, K. 1987. Approaches to Syllabus Design for Foreign Language Teaching. New Jersey: Prentice-Hall Inc. p. 1012

${ }^{21}$ Brown, J.D. 1995. The Elements of Language Curriculum: A Systematic Approach to Program Development. Boston, Massachusetts: Heinle \& Heinle Publishers. (see also Long and Crooks, 1993 as cited in Hadley, ) p. 12

${ }^{22}$ Nunan, D. 1989. Syllabus Design. Hong Kong: Oxford University Press. P.27-60 gradually $^{23}$. It includes task-based, procedural, notional/ functional (Wilkins, 1976), content-based and negotiated syllabus. In contrast, analytic syllabuses are organized in terms of the purposes for which people intend to learn the language and the kinds of language performance that are necessary to fulfill those objectives. They are structural, situational and notional/ functional syllabus. ${ }^{24}$ From the plenty types of syllabus, Rajaee Nia, Abbaspor \& Zare (2012) and Martin (1997) suggested to take an electic approach where the syllabus designer can both do away with the disadvantages of each approach and meet the specific needs of the learners. ${ }^{25}$

More recently, language curriculum design has used both genre and content as the focus of the syllabus. The Text-Based Syllabus or Genre-Approach uses the Hallidayan notions of genre or text as the organizing principle of the syllabus. It views language as whole texts (spoken and written) that are embedded in social contexts, created and used by people to achieve social purposes. The texts used in a curriculum are selected according to learners' needs and the social contexts they want to participate in. $^{26}$

${ }^{23}$ Rajaee Nia, M., Abbaspour, E., \& Zare, J. 2012. A Critical Review of Recent Trends in Second Language Syllabus Design and Curriculum Development. International Journal of Research Studies in Language Learning Vol.2 (2), 63-82

${ }^{24}$ Long, M. \& Crookes, G. 1993. Three Approaches to Task-Based Syllabus Design. TESOL Quarterly, 26, 27

${ }^{25}$ Rajaee Nia, Abbaspor \& Zare. 2012. Op. cit and Martin. 1997. Op. cit

${ }^{26}$ Burns, Joyce \& Gollin,1996 in Graves, K. 2008. The Language Curriculum: A Social 


\section{Textbook}

Textbooks as one of sources of instructional materials have become the center of language learning and teaching and been one of the most important influences on what happens in the classroom ${ }^{27}$. Nunan (1991) underlines that using textbook can remove much of the burden and time involved in creating materials from scratch, moreover, the creation of materials can be particularly burdensome in foreign (as opposed to second) language contexts, where authentic source and stimulus materials may not be readily available. That is why, most teachers use course book (textbook) to facilitate language learning and assist students to acquire and develop their English language proficiency. $^{28}$

Moreover, according to Nation \& Macalister (2010), there are several reasons why teachers use and follow the course book closely: ${ }^{29}$

1. School or ministry of education demanding

2. The teacher may be inexperienced or largely untrained and there is security in following the set course book closely.

3. The teacher is convinced of the high quality of the coursebook.

Contextual Perspective. Language Teaching. 41:2, 147-181

${ }^{27}$ Kitao, K., \& Kitao, S.K. 1997. Selecting and Developing Teaching/Learning Materials. Retrieved from http://iteslj.org/Articles/Kitao-materials.html

${ }^{28}$ Nunan, D. 1991. Language Teaching Methodology: A Textbook for Teachers. Hertfordshire: Prentice Hall. P. 209-210

${ }^{29}$ Nation, I.S.P and Macalister, J. 2010. Language Curriculum Design. New York and London: Routledge. P. 160
4. The learners wish to cover every part of the course book.

The amount of reliance placed on the course book by the teacher and the extent to which he or she depends on the books is indicative of the perceived place of the course book in the whole teaching and learning process ${ }^{30}$. Therefore, it is important to select textbooks in order to match the materials with the goals and objectives of the language program, and to ensure that they are consistent with teacher's beliefs about the nature of language and learning, as well as with learners' needs, attitudes, beliefs, and preferences $^{31}$. This condition can be achieved through a process of adaptation $^{32}$. Without careful consideration, using textbooks can deskill teachers and rob them from their capacity to think professionally and respond to their students. ${ }^{33}$

\section{The Advantages and Disadvantages of a Textbook}

The use of a textbook in teaching has both advantages and disadvantages, depending on how they are used and the context for their use. According to Graves

\footnotetext{
${ }^{30}$ Cunningsworth, A. 1995. Choosing Your Coursebook. Oxford: Macmillan Heinemann. P. 9-10

${ }^{31}$ Graves, K. 1996. Teachers as Course Developers. New York: Cambridge University Press. p. 13

${ }^{32}$ Brown, J.D. 1995. Op. cit. p. 139

${ }^{33}$ Crawford, J. 2002. The Role of Materials in the Language Classroom: Finding the Balance. In J.C., Richard, \& W.A., Renandya. Methoology in Language Teaching: An Anthology of Current Practice (pp. 80-89). New York: Cambridge University Press.
} 
(2000), the advantages of using textbooks are: ${ }^{34}$

a. It provides a syllabus for the course because the authors have made decisions about what will be learned and in what order.

b. It provides security for the students because they have a kind of road map of the course: they know what to expect, they know what is expected of them.

c. It provides a set of visuals, activities, reading, etc., and so saves the teacher time in finding or developing such materials.

d. It provides teachers with a basis for assessing students' learning.

e. It may include supporting materials (e.g. teachers' guide, cassettes, worksheets, video).

f. It provides consistency within a program across a given level, if all teachers use the same textbook.

In line with Graves' ideas, Richard (2001) states eight advantages of textbook, namely: ${ }^{35}$

a. It provides structure and a syllabus for a program.

b. It helps to standardize instruction.

c. It maintains quality

d. It provides a variety of learning resources.

e. It is efficient

f. It can provide effective language model and input

g. It can train the teacher

$\mathrm{h}$. It is visually appealing

Nevertheless, there are also negative effects of textbooks described as follows:

${ }^{34}$ Graves, K. 2000. Designing Language Courses: A Guide for Teachers. Boston: Thomson Heinle \& Heinle. P. 174

${ }^{35}$ Richard, J.C. 2001. Op. cit. p. 224-225 a. The content or examples in the textbook may not be relevant or appropriate to the target group.

b. The content might not be in the right level.

c. There may be too much focus on one or more aspects of language and not enough focus on others.

d. There may not be the right mix of activities

e. The sequence is lockstep.

f. The activities, readings, visuals, are may be boring

g. The material may go out of date.

h. The timetable for completing the textbook or parts of it may be unrealistic. $^{36}$

With different point of view, Richard (2001) lists some potential negative effects of textbook as stated below.

a. Textbook may contain inauthentic language

b. Textbook may distort content

c. Textbook may not reflect students' needs

d. Textbook deskill teachers

e. Textbook are expensive ${ }^{37}$

It is necessary to realize that no commercial textbooks will ever be a perfect fit for a particular context. A book may be ideal in one situation because it matches the needs of that situation perfectly. The same book in a different situation, on the other hand, may turn out to be quite unsuitable in that there is too little material, it does not meet with students' needs, it is not relevant with the teachers' belies, and it has element that are not needed in the $\operatorname{program}^{38}$. Consequently, selecting the right

\footnotetext{
${ }^{36}$ Graves, K. 2000. Designing Language Courses: A Guide for Teachers. Boston: Thomson Heinle \& Heinle. P. 174-175

${ }^{37}$ Richard, J.C. 2001. Op. cit. p. 225-256

${ }^{38}$ Ibid. p. 256
} 
textbook that nearly meets students' needs and relevant to the given context is requisite.

According to Cunningsworth (1995), selecting textbooks requires matching the materials with the context in which it is going to be used. For that reason, Cunningsworth (1995) proposes four criteria for evaluating textbooks: ${ }^{39}$

a. They should correspond to learner's needs. They should match the aims and objectives of the language learning program.

b. They should reflect the uses (present or future) that learners will make of the language. Textbooks should be chosen that will help equip students to use language effectively for their own purposes.

c. They should take account of students' needs as learners and should facilitate their learning process, without dogmatically imposing a rigid 'method'.

d. They should have a clear role as a support for learning. Like teachers, they mediate between the target language and the learner.

To further evaluate the chosen textbooks, Graves (2000) suggests two facets to evaluate a textbook. The first is the textbook itself: "getting inside it" to understand how it is constructed and why it is developed that way. Getting inside the textbook is important to know what the teacher is adapting and supplementing. The second is everything other than the textbook: the context, the students, and the teacher. The second facet is even more important because this point helps the teacher to be clear about what he/she is adapting it to. ${ }^{40}$

\section{Method}

Based on research questions, this research includes in document analysis of educational files that can prove to be an extremely valuable source of data ${ }^{41}$. It is "a technique that enables researchers to study human behaviour in an indirect way through analysis of their communication" 42 including textbooks. In this study, document analysis provided a major source for collecting data. Through a comprehensive review of literature indicators for various aspects of a quality for textbook were identified.

There were two books analyzed in this research. The first book was Bahasa Inggris Sekolah Menengah Pertama Kelas VIII Edisi 4 published by Pusat Pembukuan Departemen Pendidikan Nasional. This book includes in BSE (Buku Sekolah Elektronik) that has been fulfill the requirements as standard course book for junior high school students. The second book was English on Sky (EOS) 2 for Junior High School Students Year III Erlangga publisher.

In answering the first research question, "what types of syllabus is reflected in Junior high school text books?", this research employed types of syllabus coding taken from the features of each types of syllabus proposed by Dubin \& Olsthain (1987), Graves (2008)

${ }^{40}$ Graves, K. 2000. Op. cit. p. 78

${ }^{41}$ Bell, J. 2005. Doing Your Research Project $\left(5^{\text {th }}\right.$ edition). Milton Keynes: Open University Press. p. 21

${ }^{42}$ Fraenkel, J. R. \& Wallen, N. E. 2006. How to Design and Evaluate Research in Education. New York: McGraw Hill. p. 478 
and Krahnke (1987). For the second research question analysis, "what types of reading tasks are reflected in junior high school textbooks?", this research adapted from Anderson, Bechman, Perkin, and Cohen's (1991 cited in Sidek, 2010) study which categorizes reading tasks into three categories; identifying of main ideas, identifying details and drawing inferences. The last research question, what levels of cognitive demand are reflected in reading tasks of junior high school textbooks? was analyzed by Marzano et al.'s Core Thinking Skills taxonomy (1988) and Marzano's Cognitive System taxonomy (2000). ${ }^{43}$

\footnotetext{
${ }^{43}$ Sidek, H. M. 2010. Op. cit.
} 


\begin{tabular}{|c|c|c|c|}
\hline $\begin{array}{l}\text { Cognitive } \\
\text { Skill }\end{array}$ & Explanation & Example & $\begin{array}{c}\text { Level of } \\
\text { Cognitiv } \\
\text { e }\end{array}$ \\
\hline a. Focusing & $\begin{array}{l}\text { Attending to a specific } \\
\text { information and disregarding } \\
\text { others }\end{array}$ & $\begin{array}{l}\text { Read sentences aloud to } \\
\text { practice the selected sounds; } \\
\text { Read aloud and observe } \\
\text { pronunciation }\end{array}$ & Low \\
\hline $\begin{array}{l}\text { b. Recalling/ } \\
\text { Remembering }\end{array}$ & $\begin{array}{l}\text { Retrieving information from } \\
\text { long-term memory }\end{array}$ & $\begin{array}{l}\text { Read a text and recall what the } \\
\text { text is about; Listen to a text } \\
\text { and recall important details }\end{array}$ & Low \\
\hline $\begin{array}{l}\text { c. Information } \\
\text { gathering }\end{array}$ & $\begin{array}{l}\text { Obtaining information through } \\
\text { one or more senses or seeking } \\
\text { information through inquiry }\end{array}$ & $\begin{array}{l}\text { Read topics of current interests; } \\
\text { Obtain information from } \\
\text { various reading materials; }\end{array}$ & Low \\
\hline d. Organizing & $\begin{array}{l}\text { 1. Comparing: Comparing } \\
\text { information regarding } \\
\text { similarities and differences } \\
\text { 2. Classifying: Grouping and } \\
\text { labeling entities on the basis } \\
\text { of their attributes } \\
\text { 3. Ordering: Sequencing } \\
\text { information according to } \\
\text { specified criteria } \\
\text { 4. Representing: Changing the } \\
\text { form but not the substance of } \\
\text { the information }\end{array}$ & $\begin{array}{l}\text { 1. Comparing (e.g., Read a } \\
\text { dialogue and compare and } \\
\text { contrast two products) } \\
\text { 2. Classifying (e.g., Read an } \\
\text { extract and do matching } \\
\text { exercise) } \\
\text { 3. Ordering (e.g., Read an } \\
\text { passage and do sequencing } \\
\text { exercise) } \\
\text { 4. Representing (e.g., Read a } \\
\text { passage and complete a } \\
\text { diagram) }\end{array}$ & High \\
\hline e. Applying & $\begin{array}{l}\text { Using relevant prior knowledge } \\
\text { within a new situation }\end{array}$ & $\begin{array}{l}\text { Encourage learner to tell about } \\
\text { certain characters or events in } \\
\text { the story that reminds them of a } \\
\text { certain character and events in } \\
\text { real life }\end{array}$ & High \\
\hline
\end{tabular}




\begin{tabular}{|c|c|c|c|}
\hline f. Analyzing & $\begin{array}{l}\text { 1. Identifying details: } \\
\text { Determining characteristics } \\
\text { or parts of something } \\
\text { 2. Identifying relationships and } \\
\text { patterns: Recognizing ways } \\
\text { in which elements are related } \\
\text { 3. Identifying main idea: } \\
\text { Identifying the central } \\
\text { element such as hierarchy of } \\
\text { key ideas or line of reasoning } \\
\text { 4. Identifying errors: } \\
\text { Recognizing logical fallacies } \\
\text { and correcting them where } \\
\text { possible }\end{array}$ & $\begin{array}{l}\text { 1. Identifying details (e.g., } \\
\text { Read a passage and answer } \\
\text { question on details in the } \\
\text { passage) } \\
\text { 2. Identifying relationships and } \\
\text { patterns (e.g., Read a } \\
\text { passage and identify cause } \\
\text { and effects) } \\
\text { 3. Identifying main idea (e.g., } \\
\text { Read a passage and identify } \\
\text { main ideas) } \\
\text { 4. Identifying errors (e.g., } \\
\text { Read a passage and do true } \\
\text { or false exercise) }\end{array}$ & High \\
\hline g. Synthesizing & $\begin{array}{l}\text { Identification of the most } \\
\text { important components and } \\
\text { deletion of insignificant } \\
\text { information }\end{array}$ & $\begin{array}{l}\text { Read a story and draw } \\
\text { conclusion }\end{array}$ & High \\
\hline h. Generating & $\begin{array}{l}\text { 1. Inferring: Going beyond text } \\
\text { information to claim what } \\
\text { can be reasonably true } \\
\text { 2. Predicting: Anticipating next } \\
\text { events, or the outcome of a } \\
\text { situation } \\
\text { 3. Elaborating: Explaining by } \\
\text { adding relevant details }\end{array}$ & $\begin{array}{l}\text { 1. Inferring (e.g., Read a } \\
\text { newspaper extracts and } \\
\text { make inferences) } \\
\text { 2. Predicting (e.g., Predicting } \\
\text { outcomes from a text read) } \\
\text { 3. Elaborating (e.g., Read a } \\
\text { train schedule and write an } \\
\text { expanded description of the } \\
\text { schedule) }\end{array}$ & High \\
\hline i. Integrating & $\begin{array}{l}\text { 1. Summarizing: Combining } \\
\text { information efficiently into } \\
\text { cohesive statement } \\
\text { 2. Restructuring: Changing } \\
\text { existing knowledge structures } \\
\text { to incorporate new } \\
\text { information }\end{array}$ & $\begin{array}{l}\text { 1. Summarizing (e.g., Read a } \\
\text { newspaper extract and select } \\
\text { relevant point to do a } \\
\text { summary) } \\
\text { 2. Restructuring (e.g., Read a } \\
\text { sample essay as a model and } \\
\text { write an essay of a similar } \\
\text { topic) }\end{array}$ & High \\
\hline j. Evaluating & $\begin{array}{l}\text { 1. Establishing criteria: Setting } \\
\text { standards for making } \\
\text { judgments } \\
\text { 2. Verifying: Confirming the } \\
\text { accuracy of claims }\end{array}$ & $\begin{array}{l}\text { 1. Establishing criteria (e.g., } \\
\text { Discuss values explored in } \\
\text { the reading text) } \\
\text { 2. Verifying (e.g., Give } \\
\text { opinion of a story read and } \\
\text { provide reasons) }\end{array}$ & High \\
\hline
\end{tabular}




\section{Findings and Discussion}

The reflection of English reading curriculum in Junior high school textbooks can be seen in the following data description.
1. Types of Syllabus in Junior High School Text Books

Types of syllabus reflected in Junior High School textbooks can be seen from their contents.

Table 1. Content of BSE and EOS

\begin{tabular}{ll}
\hline \multicolumn{1}{c}{ BSE } & \multicolumn{1}{c}{ EOS } \\
\hline Unit 1 Congratulation & Unit 1 The Amazing Muse \\
Unit 2 Tell Me Your Experience (Recount) & Unit 2 Busy People \\
Unit 3 What Do You Do For Fun & Unit 3 My Experience \\
Unit 4 Let's Go Some Where (Descriptive) & Unit 4 Science and Experience \\
Unit 5 What Do You Think? & Unit 5 Once Upon the Time \\
Unit 6 Once Upon the Time (Narrative) & Unit 6 The Magic of Stories \\
Unit 7 Making Telephone Calls & Unit 7 Fame and Fortune \\
Unit 8 It Happened Like This (Recount) & Unit 8 A Funny Thing Happened \\
\hline
\end{tabular}

The table shows that both BSE and EOS can be categorized into situational syllabus, because it represents list of situation. ${ }^{44}$ Besides, the textbooks also reflect of text-based syllabus. It is indicated by types of text stated clearly in BSE (such as recount, descriptive and narrative) and language used in EOS (such as my experience for recount text, once upon the time for narrative). These textbooks view language as whole texts (spoken and written) that are embedded in social contexts, created and used by people to achieve social purposes. ${ }^{45}$ Comparing to what have been stated in the curriculum, both BSE and EOS have reflected the curriculum demand in the syllabus since English curriculum for junior high school adopts genre based approach.
2. Types of Reading Tasks in Junior High School Textbooks

This section presents the findings of the second research question: what types of reading tasks are reflected in Junior High School textbook. To answer this research question, reading tasks elicited from the selected documents were assigned into three categories: Identifying details, identifying main ideas, and making inferences. ${ }^{46}$

${ }^{44}$ Krahnke, K. 1987. Op. cit.

${ }^{45}$ Graves, K. 2008. The Language Curriculum: A Social Contextual Perspective. Language Teaching. 41:2, 147-181

${ }^{46}$ Sidek, H. M. 2010. Op.cit. 
Table 2. Types of Reading Task

\begin{tabular}{cccc}
\hline $\begin{array}{c}\text { Types of reading } \\
\text { task }\end{array}$ & Details & Main ideas & Inference \\
\hline BSE & $80 \%$ & $7,8 \%$ & $9,8 \%$ \\
EOS & $46,3 \%$ & $9,8 \%$ & $14,6 \%$ \\
\hline
\end{tabular}

The table indicates that both BSE and EOS applied three types of reading task. It can be seen that BSE has higher frequency in identifying details than EOS. Meanwhile, EOS has higher frequency identifying main ideas, and making inferences than BSE. It was also found other types of reading tasks in both textbooks. There is one reading task related to generic structure in BSE and there were twelve other reading tasks found including seven generic structure tasks and five grammatical features tasks in EOS.

Regarding to basic competence of reading in English Junior High School curriculum, there are some reading tasks that can be arranged. For the first basic competence, reading aloud with Received Pronunciation and appropriate intonation, the task can be in form of phonological practice. For the second basic competence which is responding meaning of simple short functional written text, can be applied by identifying information of reading task. The task forms of the second basic competence are identifying main idea, identifying details information and identifying unstated information (doing inferences). The last basic competence, responding meaning and rhetoric of simple short essay, can be assessed by using generic structure and lexico-grammatical reading tasks.

Based on the reading curriculum, EOS textbook has been reflected five types of reading tasks, namely identifying main idea, identifying details, doing inferences, identifying generic structure and identifying lexico-grammatical features. In other words, one reading task has not been reflected in SOS. On the other hand, BSE has been reflected four types of reading task comprising identifying main idea, identifying details, doing inferences, and identifying generic structure. This textbook missed two types of reading task demanded in reading curriculum. Therefore, both BSE and EOS do not fulfill all the curriculum demands in terms of reading tasks.

\section{Cognitive Level of Reading Task} in Junior High School Books

Levels of cognitive demand of the reading tasks reflected in Junior High School textbooks were coded for ten categories of cognitive demand categories proposed by Marzano et al. (1988) and Marzano (2000). 
Table. 3 cognitive level of reading task

\begin{tabular}{|c|c|c|c|c|c|c|c|c|c|c|}
\hline Level & \multicolumn{3}{|c|}{ Low Cognitive Demand } & \multicolumn{7}{|c|}{ High Cognitive Demand } \\
\hline Textbooks & Focusing & Recalling & $\begin{array}{c}\text { Information } \\
\text { gathering }\end{array}$ & Organizing & Applying & Analyzing & Synthesizing & Generating & Integrating & Evaluating \\
\hline BSE & - & - & - & - & - & $90 \%$ & $5,8 \%$ & $3,9 \%$ & & \\
\hline EOS & - & - & - & - & $15 \%$ & $71 \%$ & $7,3 \%$ & $7,3 \%$ & & \\
\hline
\end{tabular}

The table shows that the Junior High School textbooks incorporate reading tasks that require the higher level cognitive demands as proposed by Marzano et al. (1988) and Marzano (2000). BSE comprises $90 \%$ of reading tasks focusing on analyzing, 5,8 \% of reading task focusing on synthesizing and 3,9\% focusing on generating. Meanwhile, EOS employs $71 \%$ of reading task focusing on analyzing, $15 \%$ focusing on applying, 7,3\% focusing on synthesizing and $7,3 \%$ focusing on generating. In general, table shows that approximately 80 $\%$ of the reading tasks in Junior High School textbooks require high cognitive demand. It is in line with past studies which indicate the importance of training students with reading tasks that require high cognitive demand for academic purpose (e.g., Alderson, 1990; Alderson \& Lukmani, 1989; Bernhardt, 1983; Connor, 1997; Davey, 1988) ${ }^{47}$.

However, basic competences of reading in English junior high school curriculum show different levels of reading task. For the first basic competence, reading aloud with Received Pronunciation and appropriate intonation, the task can be indicated in low cognitive demand on the level of focusing. For the second basic competence which is responding meaning of

${ }^{47}$ Sidek, H. M. 2010. Ibid. simple short functional written text, can be categorized into high cognitive demand on analyzing level. The last basic competence, responding meaning and rhetoric of simple short essay, includes in high cognitive demand on applying level.

Comparing to English reading curriculum, cognitive reading tasks in junior high school textbooks was higher than what the curriculum hopes. Therefore, levels of cognitive demand of the reading tasks in both BSE and EOS do not reflect levels of cognitive demand of the reading tasks in English reading curriculum of Junior High School.

\section{E. Conclusion and Recommendation}

Based on the analysis of the study, it can be concluded that both BSE and EOS still have weakness in reflecting curriculum demand in textbook. However, BSE is likely better than EOS in terms of reflecting reading task and cognitive level of reading task of English reading curriculum of Junior High School. Finally, both BSE and EOS are needed to improve types of reading tasks in order to fulfill the curriculum demand.

On the basis of these findings, the possible causes of misinterpreting of English reading curriculum of grade VIII of Junior high school by the authors of English textbook are (1) the difficulties in placing reading task in textbooks, (2) and / or unclear 
language used in explaining types of reading tasks that should be provided for students at grade VIII. Therefore, it recommends to the curriculum developers to use unambiguous sentences in stating competence standard and basic competence; and do situational analysis for the appropriateness of reading task in textbooks. In this case, curriculum developers also need to do linguistics analysis for language used in curriculum. It is important because curriculum includes in policy, so linguistics analysis is needed ${ }^{48}$. Mistakes in using language in curriculum text will cause misinterpretation in realizing the curriculum into textbooks. Moreover, the curriculum developer is also advised to conduct ethnography method to know whether language used curriculum is understandable or not. It is similar to the use of ethnography in determining language policy. ${ }^{49}$ It is hoped that through these ways, the authors of textbook can provide appropriate English textbooks which reflect English reading curriculum.

\section{References}

Alamri, A. A. M. 2008. Textbook for Saudi Boys' Schools. Unpublished Thesis. The College of Arts. King Saud University.

Al-Murabit, I. A. 2012. A Closer Look at an English Language

${ }^{48}$ Wodak, R. 2006. Linguistic Analysis in Language Policies. In Thomas Ricento, An Introduction to Language Policy: Theory and Method. Oxford: Blackwell Publishing. P. 170171

49 Canagarajah, S. 2006. Ethnographic Methods in Language Policy. In Thomas Ricento, An Introduction to Language Policy: Theory and Method. Oxford: Blackwell Publishing. P. 164
Curriculum of a Community College in Saudi Arabia. English Language Teaching. Vol. 5 No. 8, 226-242.

Aytug, S. 2007. An EFL Textbook Evaluation Study in Anatolian High Schools: 'New Bridge to Success for 9th Grade New Beginners'. Unpublished Thesis. Ankara: The Department of Teaching English as a Foreign Language. Bilkent University.

Bell, J. 2005. Doing Your Research Project $\left(5^{\text {th }}\right.$ edition). Milton Keynes: Open University Press.

Blachowicz, C. \& Ogle, D. 2008. Reading Comprehension: Strategies for Independent Learners. $\left(2^{\text {nd }} e d\right)$. New York: Guilford Press.

BNSP. (2006). Kurikulum Tingkat Satuan Pendidikan: Standar Kompetensi dan Kompetensi Dasar. Jakarta: Departemen Pendidikan Nasional.

Bodegas, I. D. N. 2007. From curriculum to syllabus design: The different stages to design a programme. Memorias Del Iii Foro Nacional De Estudios En Lenguas (FONAEL 2007). Universidad de Quintana Roo Departamento de Lengua y Educación. http://www.fonael.org - fonael@fonael.org.

Brown, J.D. 1995. The Elements of Language Curriculum: A Systematic Approach to Program Development. Boston, Massachusetts: Heinle \& Heinle Publishers.

Çakit, I. 2006. Evaluation of the Efl Textbook "New Bridge To Success 3" from the Perspectives of Students and Teachers. 
Unpublished Thesis. Graduate School of Social Sciences of The Middle East Technical University.

Canagarajah, S. 2006. Ethnographic Methods in Language Policy. In Thomas Ricento, An Introduction to Language Policy: Theory and Method. Oxford: Blackwell Publishing.

Crawford, J. 2002. The Role of Materials in the Language Classroom: Finding the Balance. In J.C., Richard, \& W.A., Renandya. Methoology in Language Teaching: An Anthology of Current Practice (pp. 80-89). New York: Cambridge University Press.

Cunningsworth, A. 1995. Choosing Your Coursebook. Oxford: Macmillan Heinemann.

Dubin, F and Olshtain, E. 1987. Course Design: Developing Programs and Materials for Language Learning. Cambridge, New York and Melbourne: Cambridge University Press.

Fraenkel, J. R. \& Wallen, N. E. 2006. How to Design and Evaluate Research in Education. New York: McGraw Hill.

Graves, K. 2000. Designing Language Courses: A Guide for Teachers. Boston: Thomson Heinle \& Heinle.

2008. The Language Curriculum:

A Social Contextual Perspective. Language Teaching. 41:2, 147181).

1996. Teachers as Course
Developers. New York:
Cambridge University Press.

Hadley, G. Examining the Underlying Principles of EFL Syllabus Design. PDF files.

Kayapinar, U. 2009. Coursebook Evaluation by English Teachers. Inonu University Journal of the Faculty of Education. Volume. 10, Issue. 1, pp. 69-78.

Kitao, K., \& Kitao, S.K. 1997. Selecting and

Developing

Teaching/Learning Materials. Retrieved from http://iteslj.org/Articles/Kitaomaterials.html.

Krahnke, K. 1987. Approaches to Syllabus Design for Foreign Language Teaching. New Jersey: Prentice-Hall Inc.

Ling, Y. C., Tong, C. S., \& Jin, N. Y. 2012. Evaluating the ESL Reading Texts for Intermediate Learners of English from the Perspective of Students. Global Journal of Human Social Science. Volume 12 Issue 7.

Long, M. \& Crookes, G. 1993. Three Approaches to Task-Based Syllabus Design. TESOL Quarterly, 26, 27.

McGrath, I. (2002). Materials Evaluation and Design for Language Teaching. Edinburgh: Edinburgh University Press Ltd.

Nation, I.S.P and Macalister, J. 2010. Language Curriculum Design. New York and London: Routledge.

Nation, P. Designing and Improving a Language Design. PDF files.

Nunan, D. 1989. Syllabus Design. Hong Kong: Oxford University Press.

Nunan, D. 1991. Language Teaching Methodology: A Textbook for 
Teachers. Hertfordshire: Prentice Hall.

Patel, M. F \& Jain, P. M. 2008. English Language Teaching (Methods, Tools \& Techniques). Jaipur: Sunrise Publishers \& Distributors.

Rajaee Nia, M., Abbaspour, E., \& Zare, J. 2012. A Critical Review of Recent Trends in Second Language Syllabus Design and Curriculum Development. International Journal of Research Studies in Language Learning Vol.2 (2), 63-82.

Richard, J.C. 2001. Curriculum Development in Language Teaching. New York: Cambridge University Press.

Sidek, H. M. 2010. An Analysis of the EFL Secondary Reading Curriculum in Malaysia: Approaches to Reading and Preparation for Higher
Education. Unpublished Thesis. University of Pittsburgh.

Soleimani, H \& Dabbaghi, A. 2012. Textbook evaluation: A reflection on the New Interchange Series. International Journal of Research Studies in Language Learning. Volume 1 Number 2, 19-32.

The Southern African Development Community Ministries of Education. 2000. Module 14: Curriculum Practice. The Commonwealth of Learning.

Tok, H. 2010. TEFL Textbook Evaluation: From Teachers' Perspectives. Educational Research and Review Vol. 5 (9), pp. 508-517.

Wodak, R. 2006. Linguistic Analysis in Language Policies. In Thomas Ricento, An Introduction to Language Policy: Theory and Method. Oxford: Blackwell Publishing. 